\title{
Veb-Resursların Analitikasının Mövcud Vəziyyəti və Problemlori
}

\author{
Yusif Sadiyev \\ AMEA İnformasiya Texnologiyaları İnstitutu, Bakı, Azərbaycan \\ sadiyev.yusif@gmail.com, sadiyev.yusif@mail.ru
}

\begin{abstract}
Xülasə-Məqalədə Veb-analitikaya ümumi olaraq nəzər salınıb. Veb-resursların göstəricilərinin qiymətləndirilməsinin intelektual analizi, hal-hazırda bu sahədə mövcud vəziyyət və problemlər araşdırılıb toqdim olunmuşdur. Veb-resursların analitikasının aparıldığıplatformalara baxılmışvə problemlər qeyd edilmişdir.
\end{abstract}

Açar sözlor- İp-analitika, Veb-analitika, Veb-menecment, Big Data

\section{GIRIŞ}

Dünyada veb-resursların analitikası ilə məşğul olan müxtəlif platformalar mövcuddur. Nümunə olaraq Google Analytics, Liveinternet.ru, Yahoo Web Analytics, Clicky, Yandex.Metrika, WordPress Jetpack və s. göstərmək olar. Bunlardan ən çox bazar payı olan Google Analytics-dir.

2016-ci ilin statistikası göstərir ki, 1,000,000,000 veb-sayt aktivdir və bunların da $65,5 \%$-nin analitikası müxtəlif platformalar tərəfindən aparılır. Məlumdur ki, veb-analitika zamanı toplanmış məlumatlar böyük verilənlər (Big data) yaradır. $\mathrm{Bu}$ verilənlərüzərində analitikanın aparılmasıböyük verilənlərin analizi (Big data analytics) problemini aktuallaşdırır[1].

Muasir analitikada veb-resursların analitikası ənənəvi analitika üsulları ilə yox, intelektual analitika üsullarına da baxilır.

Veb-analitikada məlumatların toplanması iki cür aparılır:

a) Loq fayllar (Log Files)- veb-resurs haqqinda informasiya serverin log fayllarında toplanır və loq analiz tətbiqləri ilə analitika aparılır $[2,5,10]$.

$\mathrm{Bu}$ informasiyanın toplanması da iki istiqamətdə olur:

$\checkmark$ Passiv molumatların toplanması (Passive Data Collection);

$\checkmark \quad$ Veb-brauzerin normal hissəsi, veb-serverin əməliyyatı (Normal part of web browser/web server transaction)

b) Səhifə etiketi (Page Tagging) - veb-səhifəyə yerləşdirilmiş kod (script) vasitəsilə məlumatların toplanmasidir $[2,5]$.

Veb-analitikada məlumatların toplanmasının hər iki üsulundan istifadə olunur. Analitika xidmətlərini təklif edən platformalar əsasən Səhifə etiketi (Page Tagging) üsulundan istifadə edir. Bu zaman veb-resurs haqqında bütün informasiya platformaların verilənlər bazasında saxlanılır və hazırlanmıs hesabatlar istifadəçiyə təqdim olunur.
Veb-analitikanın verdiyi imkanlar bu sahəyə yeni baxışların yaranmasına gətirib çıxarır və günümüzdə bu mövzunu aktual edir.

Azərbaycan İnternetseqmentində yerləşən veb-resursların böyük əksəriyyəti qeyd etdiyimiz analitika xidmətləri təklif edən platformalardan istifadə edərək statistik rəqəmlər çıxarır.

\section{VEB-ANALİTIKA: ÜMUMİ MӘLUMAT}

Veb-analitika veb-saytların statistik məlumatlarının ölçülməsi, yığılması, təhlili və hesabatlarını aparılması kimi funksiyaları özündəbirləşdirir. Həmçinin biznes marketinq tədqiqatları aparmaq və saytın səmərəliliyini qiymətləndirmək üçün istifadə olunur.Eyni zamanda veb-analitika saytın ziyarətçiləri və müraciətlərin sayı haqqında məlumat toplamağa imkan verir. Bu, tələbatın öyrənilməsi üçün faydal olan populyarlıq meyyarlarını qiymətləndirməyə kömək edir [1].Veb-saytların və ümumilikdə veb-resursların analitikası aparılarkən əsasən aşaşğıdakı istiqamətlər üzrə hesabatlar tərtib olunur:

- demoqrafik göstəricilər (yaş, cins);

- dil;

- brauzerin növü;

- zaman intervali;

- kontent;

- məkan.

Veb-analitikanın əsas tarixi mərhələləri kimi aşağıdakıları göstərmək olar:

- 1993 -cü ildə veb-saytlara olunan müraciətlər log fayllarda qeydə alınırdı $[3,6]$.

- 1993-ci ildə WebtrendsVeb-analitikaxidməti fəaliyyətə başlayıb [3] [6]

- 1995 - ci ildə ilk log fayl analizi üçün proqram hesab edilənDr. Stefan Turner Analoq-u yaradılıb [3, 6].

- 2004 - cü ildə THE WEB ANALYTICS ASSOCIATION (WAA) yaradılıb. Veb-resurslardan rəqəmsal məlumatların analizi ilə məşğul olur və 2011-ci ildə adı Digital Analytics Association olaraq dəyişdirilib [3, 6].

- 2005 -ci ildə Google şirkəti URCHIN \& LAUNCHES-Ii alaraqGoogle Analitik xidmotini təklif edib [3, 6].

Veb-analitikada 2 metrik yanaşmadan istifadə olunur: 
$>$ On-site metrik yanaşması [8];

$>$ Off-site metrik yanaşması [8].

A. On-site metrik yanaşma veb-saytın müxtəlif göstəricilər üzrə analitikasıdır və aşağıdakı məsələlərə baxılır:

$\checkmark$ Hit (Klik sayı) - veb-saytda yüklənən faylların sayınıgöstərir və buna foto, qrafika və s. aid etmək olar [3].

$\checkmark$ Page View (Səhifəyə baxış) - istifadəçinin veb-saytda müraciət etdiyi bütün səhifələrin sayını göstərir.

$\checkmark$ Visit (Ziyarət) - hər fərdi istifadəçinin veb-sayta etdiyi müraciətdir [3].

$\checkmark$ Session (Sessiya) - istifadəçinin veb-saytda qalma müddətidir. $\mathrm{Bu}$ müddət ayr1-ayrısəhifələr üçün də hesablana bilər [3].

$\checkmark$ First Visit / First Session (İlk ziyarət / İlk sessiya) -İlk dəfə veb-sayta müraciət edən ziyarətçi, ziyarətçinin ilk sessiyas 1 [3]

$\checkmark$ Visitor / Unique Visitor / Unique User (Ziyarətçi/Unikal ziyarətçi/Unikal istifadəçi) - Eyni şəbəkədən müraciət edənlərin hər biri ziyarətçi kimi qeydə alınır. Unikal istifadəçi isə İP ünvana görə Unikal kimi götürülür [3].

$\checkmark$ Repeat Visitor (Təkrar ziyarətçi) - müəyyən vaxt intervalında veb-saytı təkrar ziyarət edən istifadəçidir [3].

$\checkmark$ New User (Yeni istifadəçi) - yeni ziyarətçidən fərqli olaraq yeni istifadəçi müəyyən zaman kəsiyində veb-sayti təkrar ziyarət edirsə, artıq o ziyarətçi yox istifadəçi hesab edilir [3].

$\checkmark$ Single Page Visit / Singleton(Yalnız bir səhifəyə müraciət/ Tək predment) - ancaq bir səhifəyə müraciətdir [3].

$\checkmark$ Exit Rate /\% Exit (Çıxış reytinqi / çıxış) - müraciəst edilən sonuncu səhifənin reytinqi [3].

Session Duration / Visit Duration (Sessiya müddəti / Ziyarət müddəti) - veb-saytda yaxud səhifələrdə qalma müddəti [3].

B. Off-site metrik yanaşma açıq məlumatların təhlilidir. Veb-sayt, sosial media və ya digər İnternet resurslarından qeyd olunmuş açar sözlərə əsasən analitikanın aparılması və hesabatların hazırlanması nəzərdə tutulur [7].

\section{VEB-SAYTLARIN ANALİTIKASI: MÜASIR VӘZIYYYTİ}

Veb-saytların analitika xidmətini müxtəlif şirkətlər təklif edir. Nəzərə alaq ki, heçdə bütün saytlar analitika xidmətlərindən istifadə etmir.

Şəkil 1-dən göründüyü kimi ümumi veb-resurslar üzrə $34.5 \%$ veb-sayt heç bir analitika xidmətindən istifadə etmir, yerdə qalan $65.5 \%$ veb-sayt isəmüxtəlif analitika xidmətləri təklif edən platformalardan istifadə edir.

Qeyd olunduğu kimi, 65.5\% veb-sayt analitika xidmətindən istifadə edir. Onların paylanma faizi şəkil 2-də göstərilmişdir.

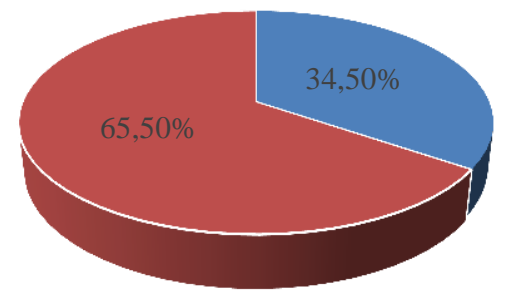

- Analitika xidmətlərindən istifadə etməyən veb-saytlar

- Analitika xidmətlərindən istifadə edən veb-saytlar

Şəkil1.Veb-saytların analitika xidmətindən istifadə etməsinə görə paylanması

\begin{tabular}{|r|c|}
\hline None & \\
\hline Google Analytics & $34.5 \%$ \\
\hline & \\
Yandex.Metrika & $5.4 \%$ \\
& $8.2 \%$ \\
WordPress Jetpack & $4.5 \%$ \\
& $6.9 \%$ \\
& $3.2 \%$ \\
LiveInternet & $4.9 \%$ \\
& $1.9 \%$ \\
New Relic & $3.0 \%$ \\
\hline
\end{tabular}

Şəkil 2. Platformaya görə veb-saytların paylanma faizi

Veb-saytların analitikasının aparılması üçün təqdim olunan kodunun (script)veb-sayta yerləşdirməsimütləqdir. On çox istifadə olunan Google Analytics platformasıdır vəonun təqdim etdiyi xidmətdən istifadə etmək üçün mütləq "gmail" hesabının olması tələb olunur.Bu hesab əsasında statistik hesablama aparmaq üçün sözügedənveb-sayt qeydiyyatdan keçirilərək verilmiş kodu (script) saytda yerləşdirilir.

Cədvəl 1-də cədvəldə bəzi şirkətlərin təqdim etdiyi analitika xidmətləri göstərilmişdir [4].

\section{VEB-ANALITIKA SAHӘSINDӘ MÖVCUD PROBLEMLӘR}

Veb-resursların analitikası aparılarkən IP analitika məsələlərinə də baxılır. Nümunə olaraq qeyd etmək olar ki, Google Analytics ilə İP analitika aparmaq üçün mütləq vebsaytda platformanınişlənmə prinspi nəzərə alınmalıdır. Yəni əlavə kod (script) vasitəsilə İP-lər qeydə alınıb Google Analytics-ə ötürülməlidir.

Veb-saytların analitikası zamanı başqa bir problem də "cookie" problemidir. "Cookie" - veb-sayt1 ziyarət edən istifadəçinin məlumatlarını brauzerdə saxlayır. Və istifadəçi veb-sayta təkrar müraciət etdikdə onun məlumatları ilk olaraq "cookie"-dən oxunur. İstifadəçilərin müəyyən faizi dəyişən İP ünvan istifadə etdiyindən hər yeni qoşulma zamanı IP ünvan dəyişir. Ona görə də hesablama İP ünvanlara görə yox, "cookie"-yə görə aparılır. Amma müəyyən vaxtdan sonra "cookie" silindiyindən istifadəçiləri "yeni istifadəçi" və "təkrar istifadəçi”" kimi növlərə bölmək problemi yaranır $[9,10]$. 
CəDVӘL1: VEB-ANALITIKIKA PLATFORMALARININ MÜQAYISəSİ

\begin{tabular}{|c|c|c|}
\hline Ad & Saytların sayı & Təqdim etdiyi xidmətlər \\
\hline $\begin{array}{l}\text { Google } \\
\text { Analytics }\end{array}$ & $12,799,388$ & $\begin{array}{ll}\text { 1. } & \text { İP analitika } \\
\text { 2. } & \text { Veb-saytın diaqnozu } \\
\text { 3. } & \text { Saat/Gün/Ay/lil-ə görə analiz } \\
\text { 4. } & \text { Açar sözlərə görə analiz } \\
\text { 5. } & \text { Linklərin analizi } \\
\text { 6. } & \text { Real vaxta görə analiz } \\
\text { 7. } & \text { Trafikin analizi } \\
\text { 8. } & \text { Demoqrafik analiz } \\
\text { 9. } & \text { Dilə görə analiz } \\
\text { 10. } & \text { Regiona görə analiz } \\
\text { 11. } & \text { Kontentin analizi }\end{array}$ \\
\hline Yandex.Metrika & $1,033,008$ & $\begin{array}{ll}\text { 1. } & \text { Real vaxta görə analiz } \\
\text { 2. } & \text { Trafikin analizi } \\
\text { 3. } & \text { Demaoqrafik analiz } \\
\text { 4. } & \text { Kontentin analizi } \\
\text { 5. } & \text { Saat/Gün/Ay/İl-ə görə analiz } \\
\text { 6. } & \text { Açar sözlərə görə analiz }\end{array}$ \\
\hline $\begin{array}{l}\text { WordPress } \\
\text { Jetpack }\end{array}$ & 288,501 & $\begin{array}{ll}\text { 1. } & \text { Statistik analiz } \\
\text { 2. } & \text { Regiona görə analiz } \\
\text { 3. } & \text { İstifadəçilərin analizi } \\
\text { 4. } & \text { Səhifələrə baxış sayına görə } \\
& \text { analiz }\end{array}$ \\
\hline LiveInternet & 643,819 & $\begin{array}{ll}\text { 1. } & \text { Real vaxta görə analiz } \\
\text { 2. } & \text { Trafikin analizi } \\
\text { 3. } & \text { Demaoqrafik analiz } \\
\text { 4. } & \text { Saat/Gün/Ay/İl-ə görə analiz }\end{array}$ \\
\hline New Relic & 73,402 & $\begin{array}{ll}\text { 1. } & \text { Real zamana görə analiz } \\
\text { 2. } & \text { Regiona görə analiz } \\
\text { 3. } & \text { İstifadəçilərin analizi } \\
\text { 4. } & \text { Səhifələrə baxış sayına görə } \\
& \text { analiz }\end{array}$ \\
\hline
\end{tabular}

Digər problem isə bu sahədə xidmətlər təklif edən platformalarınfərqli statistik rəqəmlər verməsidir.
Veb-resursların böyük əksəriyyətinin analizi və statistikası müxtəlif platformaların təqdim etdiyi xidmətlərdən istifadə edilərək aparılır. Müəyyən faizinin analitikası isə ümumiyyətlə aparılmır. Veb-resursların bütün statistik məlumatları tam olaraq bu platformalarda saxlanılır. Bütün bunlar nəzərə alaraq milli informasiya təhlükəsizliyi konsepsiyasının işlənməsi və milli-statistika sisteminin qurulması zərurəti yaranır.

\section{NӘTİCə}

Dünya üzrə veb-saytların sayında çox sürətli artım müşahidə olunur. Bəzi veb-saytların isə aktivliyinin itməsi müəyyən vaxt kəsiyindən sonra ümumiyyətlə ziyarətçilərinin sayının azalmasına gətirib çıxarır. Veb-saytların statistikasının aparılması və müqayisə olunması onların passivlik meyillərinin aşkarlanması və problemintəyin edilməsinə imkan verir.

Lakin burada "hansı platformadan istifadə etmək lazımdır?" sualı yaranır.Platormaların təqdim etdiyi statistik rəqəmlərin eyni olmaması istifadəçiləri seçim qarşısında qoyur. Veb-saytın analitikasının aparılması üçün eyni zamanda müxtəlif platformaların təqdim etdiyi xidmətlərdən istifadə etmək olar.

\section{ӘDӘBIYYYT}

[1] "Big Data Market Size and Vendor Revenues", http://wikibon.org

[2] Brian CliftonAdvanced Web Metrics with Google Analytics, 2nd edition, 2010

[3] G. Zheng, S. Peltsverger Web Analytics Overview, In book: Encyclopedia of Information Science and Technology, Third Edition, Publisher: IGI Global, Editors: Mehdi Khosrow-Pour, 2015

[4] https://www.clicktale.com/academy/blog/a-brief-history-of-webanalytics/ (14.04.2017 23:35)

[5] "Revisiting log file analysis versus page tagging": McGill University Web Analytics blog article (CMIS 530) Archived July 6, 2011, at the Wayback Machine.

[6] https://www.similartech.com/compare/google-analytics-vs-yahooanalytics (14.04.2017 23:55)

[7] B. J. Jansen, Understanding user-web interactions via web analytics. Synthesis Lectures on Information Concepts, Retrieval and Services, vol.1, no 1, pp. 1-102, 2009

[8] R. Johnson, J. Staddon, "Deflation-secure web metering". International Journal of Information and Computer Security. Vol.1, no 39, 2007

[9] International Journal of Competitive Intelligence, Strategic, Scientific and Technology Watch SciWatch Journal 1 (2008), Issue 1, pp.85 - 86

[10] T.T.Aye, "Web log cleaning for mining of web usage patterns ", Computer Research and Development (ICCRD), 2011 3rd International Conference on , pp.490-494, 2011. 